\title{
Effects of $D_{2} O$ on the Movement of Chromosomes and the Shortening of Kinetochore Spindle Fibers in Anaphase in Dividing Spermatocytes of the Grasshopper, Mongolotettix japonicus
}

\author{
Sutiman Bambang Sumitro ${ }^{1.3}$ Kosaku Izutsu $^{2}$ and Hidemi Sato ${ }^{1}$ \\ ${ }^{1}$ Sugashima Marine Biological Laboratory, School of Science, Nagoya Universi- \\ ty, Toba, Mie 517, 2Department of Pathology, Mie University, School of \\ Medicine, Edobashi, Tsu, Mie 514, Japan and ${ }^{3}$ Department of Biology, Brawi- \\ jaya University, Sumbersari, Malang 65151, Indonesia.
}

\begin{abstract}
Spindles in anaphase of dividing primary spermatocytes of the grasshopper, Mongolotettix japonicus, were examined with a sensitive polarizing microscope combined with a time-lapse video recorder and a cinematographic apparatus. The pole-to-pole distance of the meiotic spindles was increased and the kinetochore fibers were more birefringent in the presence of $40 \% \mathrm{D}_{2} \mathrm{O}$. However, the rate of shortening of the kinetochore fibers in anaphase was not affected by $\mathrm{D}_{2} \mathrm{O}$. This indicates that $\mathrm{D}_{2} \mathrm{O}$ did not inhibit microtubule disassembly in anaphase, supporting the earlier observations $(3$, 18) that $\mathrm{D}_{2} \mathrm{O}$ did not "stabilize" the spindle microtubules at concentrations below $45 \%$. We confirmed that $\mathrm{D}_{2} \mathrm{O}$, at the concentration mentioned above, neither promotes nor inhibits the anaphase $\mathrm{A}$. However, the overall sequence of anaphase was considerably extended in the presence of $\mathrm{D}_{2} \mathrm{O}$, presumably due to the increased pole-to-pole distance.
\end{abstract}

When $\mathrm{D}_{2} \mathrm{O}$ is applied to the dividing eukaryotic cells at concentrations less than $45 \%$, both the spindle volume and birefringence $(B R)$ are increased $(3,13,16)$, but mitosis is not inhibited $(3,18)$. Based on experiments using the dividing sea urchin eggs, Takahashi and Sato $(17,18)$ considered the extension of anaphase duration in $\mathrm{D}_{2} \mathrm{O}$-treated cells could be caused by the elongation of the spindle axis in the presence of $\mathrm{D}_{2} \mathrm{O}$. In the present experiment, we intended to reexamine their observations using dividing primary spermatocytes of the grasshopper, Mongoltettix japonicus, whose anaphase is 5 to 6 times longer than the anaphase of dividing sea urchin eggs. Spindles of these cells are large, clear $(5,6,7)$ and provide a prominent image of kinetochore fibers under a sensitive polarizing microscope $(6,7)$. We considered that spermatocytes, which possessed ample amounts of polymerizable tubulin for the spindle assembly in meiosis I and II, allowed us more precise tracing of their anaphasic sequences. We expected to obtain better information concerning the effect of $\mathrm{D}_{2} \mathrm{O}$ on the microtubule disassembly in the dividing eukaryote.

Through the present study, we found that while the BR of the non-kinetochore fibers increased little, BR of the kinetochore fibers was greatly enhanced by $\mathrm{D}_{2} \mathrm{O}$. The spindles were elongated and in many occasions their poles reached the cell membrane. In this paper, we shall report the process of shortening of the kinetochore-to- 
pole distance, the rate of chromosomal movements and the change of the pole-topole distance during anaphase. Results are discussed in relation to the biological effect of $\mathrm{D}_{2} \mathrm{O}$ on the spindle assembly and disassembly in the process of anaphase.

\section{MATERIALS AND METHODS}

Primary spermatocytes of the Japanese grasshopper, Mongolotettix (Chrysochraon) japonicus, were used. They have large and more birefringent spindles with relatively few chromosomes as compared to spermatocytes of other species of grasshoppers. Their centrioles are often detectable from late prophase through telophase in life by light microscopy. Preparations for live observation were made with fluorocarbon oil, FC-47 (Minnesota Mining \& Mfg. Co., St. Paul, Minnesota) as described previously $(7,8)$ with slight modifications. Testicular follicles from individual grasshoppers were divided into two groups. One group was immersed in $0.9 \mathrm{X}$ Carlson's solution $(1,6)$ as the control. The other group was immersed in $40 \% \mathrm{D}_{2} \mathrm{O}-0.9 \mathrm{X}$ Carlson's solution. After 20 min of immersion, the testicular follicles were placed onto a slide glass, and their distal tips were cut with a sharp knife. The germ cells contained in the small amount of body fluid were then carefully taken out onto the same slide glass. Drops of FC-47 were then placed onto the cells before a coverslip $\left(18 \times 18 \mathrm{~mm}^{2}\right)$ was mounted on the latter. A piece of teflon tape (ASF-110, Chukoh Chemical Industries LTD.) with a square hole $\left(15 \times 15 \mathrm{~mm}^{2}\right)$ in the middle was used as a spacer. Finally, after absorbing the excess of FC-47 by filter paper, the edges of the coverslip were sealed with VALAP (vaselin : lanolin : paraffin $=2: 2: 1$ ).

The $\mathrm{D}_{2} \mathrm{O}$, purchased from the Bio-Rad Laboratories, Richmond, Ca. U.S.A., had specific purity of $99.86 \mathrm{M}$ percent and was used in this experiment at a final $\mathrm{v} / \mathrm{v}$ concentration of $40 \% \mathrm{D}_{2} \mathrm{O}$ in $0.9 \times$ Carlson's solution.

Polarization microscopy. A Leitz polarizing microscope (Ortholux-II Pol-BK, Leitz, West Germany) modified to be equipped with strain free, rectified condensers (Nikon, N.A. 0.52 or N.A. 1.15) and rectified objectives (Nikon, 40X, N.A. 0.65 and 100X, N.A. 1.25) was used for polarization microscopy. A Brace-Köhler type compensator $(\lambda / 30$, Leitz) was routinely used for retardation measurements. A Glan-thomson prism and a Leitz plastic polarizing filter were used as a polarizer and an analyzer, respectively. Strong illumination was provided by a super-high-pressure mercury arc lamp (HBO $200 \mathrm{~W}$, Osram, West Germany) from which the $546 \mathrm{~nm}$ green light was isolated using a filter system which consisted of a heat absorbing glass filter, a $5 \mathrm{~cm}$ thick liquid layer containing $20 \%$ ferrous ammonium sulfate solution, and an interference filter (Toshiba, Tokyo, Japan). The anaphasic movement in dividing primary spermatocytes was followed and recorded utilizing either a timelapse video recorder or cinemato-graphic apparatus.

Time-lapse video recording. The polarization microscope was equipped with a sensitive video camera (Hamamatsu, C-1000, type 12) connected to a time-lapse video cassette recorder (National, AG-6010). Microscope images were recorded on Sony or National $1 / 2$ inch high density VHS video tape. The time-lapse rate was either 150 or 75 frames per minute. The outlines of the cells, chromosomes, kinetochore spindle fibers and the position of centrioles during anaphase were traced on transparent plastic sheets mounted on the monitor screen. Inter kinetochore distance, length of kinetochore fibers as well as interpolar distance were measured on these tracings and plotted against time.

Time-lapse cinematography. Cinematographic records were made on Kodak Plus-X $16 \mathrm{~mm}$ negative film at 7.5 frames per minute. From a positive copy of the film, every fifth frame was traced utilizing a Shinko $16 \mathrm{~m} / \mathrm{m}$ halogen viewer. The method of analysis was the same as that of the images recorded on the video tapes. 


\section{RESULTS}

The metaphase spindle of the primary spermatocyte immersed in $40 \% \mathrm{D}_{2} \mathrm{O}$ was longer and more birefringent as compared with the spindle in control cells (Fig. 1). BR of the kinetochore spindle fibers was markedly increased, while the change of BR of non-kinetochore fibers was not conspicuous (Fig. 1B). As a result of spindle elongation, the spindle poles of $\mathrm{D}_{2} \mathrm{O}$-treated cells were often observed to reach the cell membrane (Fig. 1B; Fig. 2A). This kind of image was never seen in the control cells. The spindle in the treated cells appeared to be somewhat stiffened judging from the fact that its movement was rather restricted.

Preliminary observation showed that the $\mathrm{D}_{2} \mathrm{O}$ effects were detected but less prominent in spindles of secondary spermatocytes than spindles of the primary spermatocytes. Therefore, we decided to analyze the $\mathrm{D}_{2} \mathrm{O}$ effects only on meiosis $\mathrm{I}$ spindles of the spermatocytes.

The exact time of the onset of anaphase both in the control and the $\mathrm{D}_{2} \mathrm{O}$-treated cells was determined from measurements of the distance between bivalent kinetochores (KKD). We considered the onset of anaphase as the time when KKD started to show a gradual increase (Fig. 3). In most cells, the shortening of kinetochore-to-pole distance (KPD) began a few minutes prior to the increase of KKD. This phenomenon remained unchanged in the presence of $40 \% \mathrm{D}_{2} \mathrm{O}$ in the Carlson's medium (Fig. 4). The rate of chromosome movement at the beginning of anaphase was slow and then became progressively faster, reaching a maximum in early to mid-anaphase. The movement slowed down at the ending part of anaphase
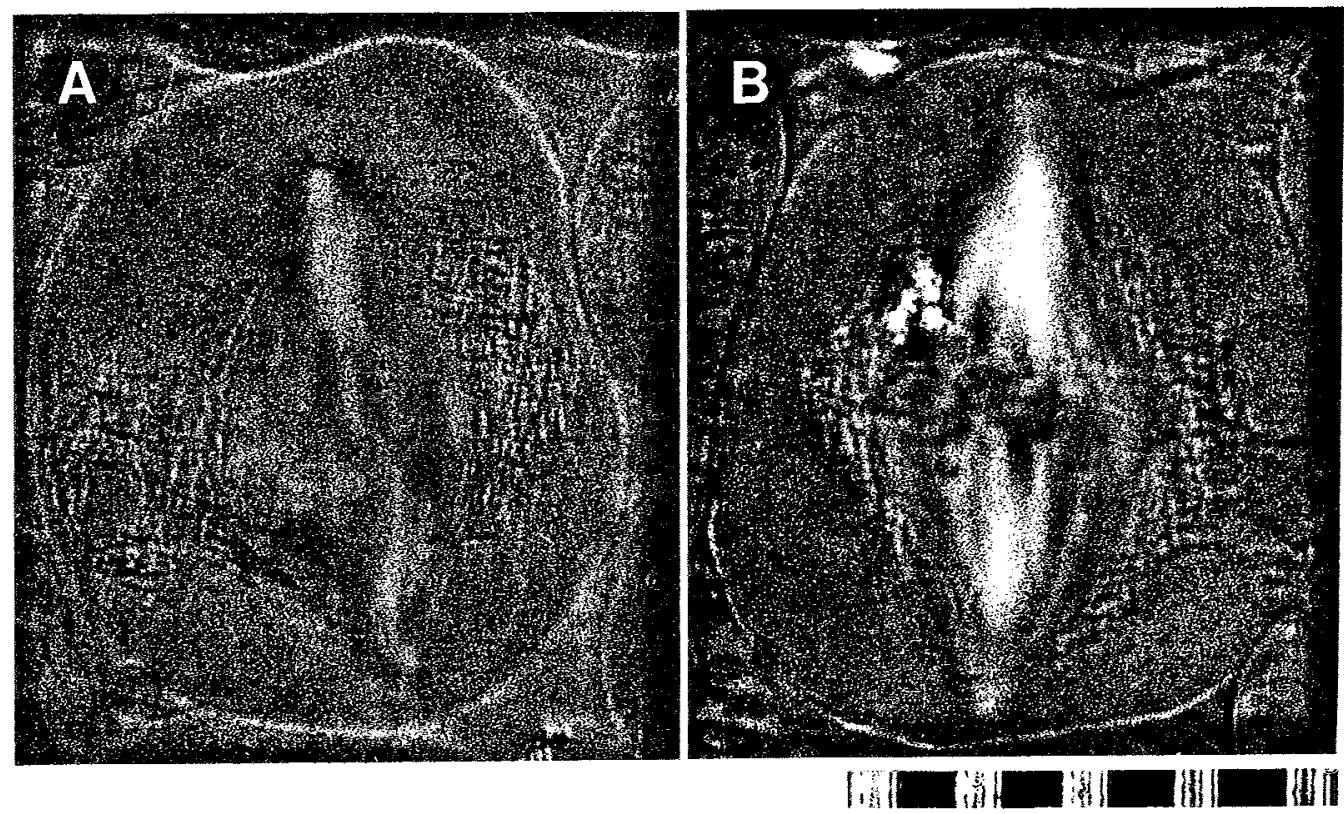

Fig. 1. A: The spindle of a control cell in metaphase as seen by polarization microscopy. B: The spindle of a cell immersed in $40 \% \mathrm{D}_{2} \mathrm{O}$-Carlson' solution in metaphase. The poles of the spindle in $\mathrm{D}_{2} \mathrm{O}$ treated cells often reached the cell membrane at metaphase, denoting a longer spindle in cells affected by $\mathrm{D}_{2} \mathrm{O}$. Temperature was $26^{\circ} \mathrm{C}$. 
(Fig. 3). The presence of $\mathrm{D}_{2} \mathrm{O}$ made the chromosome movement slower in early or early to mid-anaphase. The speed was $1.3 \pm 0.3 \mu \mathrm{m}$ per minute in the control cells, and $0.9 \pm 0.2 \mu \mathrm{m}$ per minute in $40 \% \mathrm{D}_{2} \mathrm{O}$-Carlson' solution (Table 1 ). As a consequence of the spindle elongation in $\mathrm{D}_{2} \mathrm{O}$-treated cells, when the cell proceeded through anaphase, the chromosomes had to move a longer distance to reach the poles. In fact, the anaphase took approximately 9 min longer than the control (Table 1). Despite the longer time course of anaphase sequence and the slower
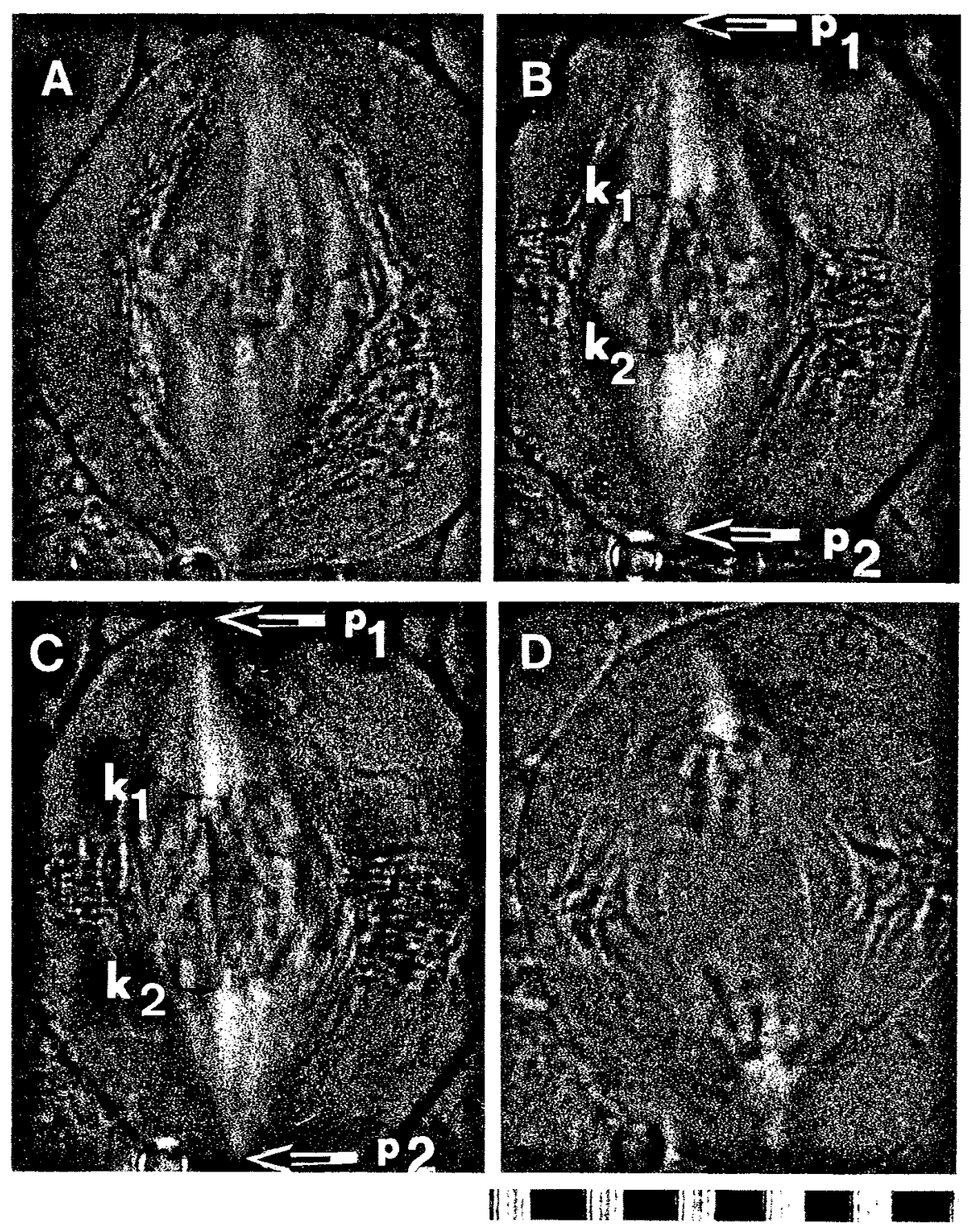

Fig. 2. Spindle transition from metaphase up to late anaphase (A-D) in a $\mathrm{D}_{2} \mathrm{O}$-treated cell. During anaphase (B, C and D) the kinetochore spindle fibers had prominent $B R$, however $B R$ was lower near the poles. 

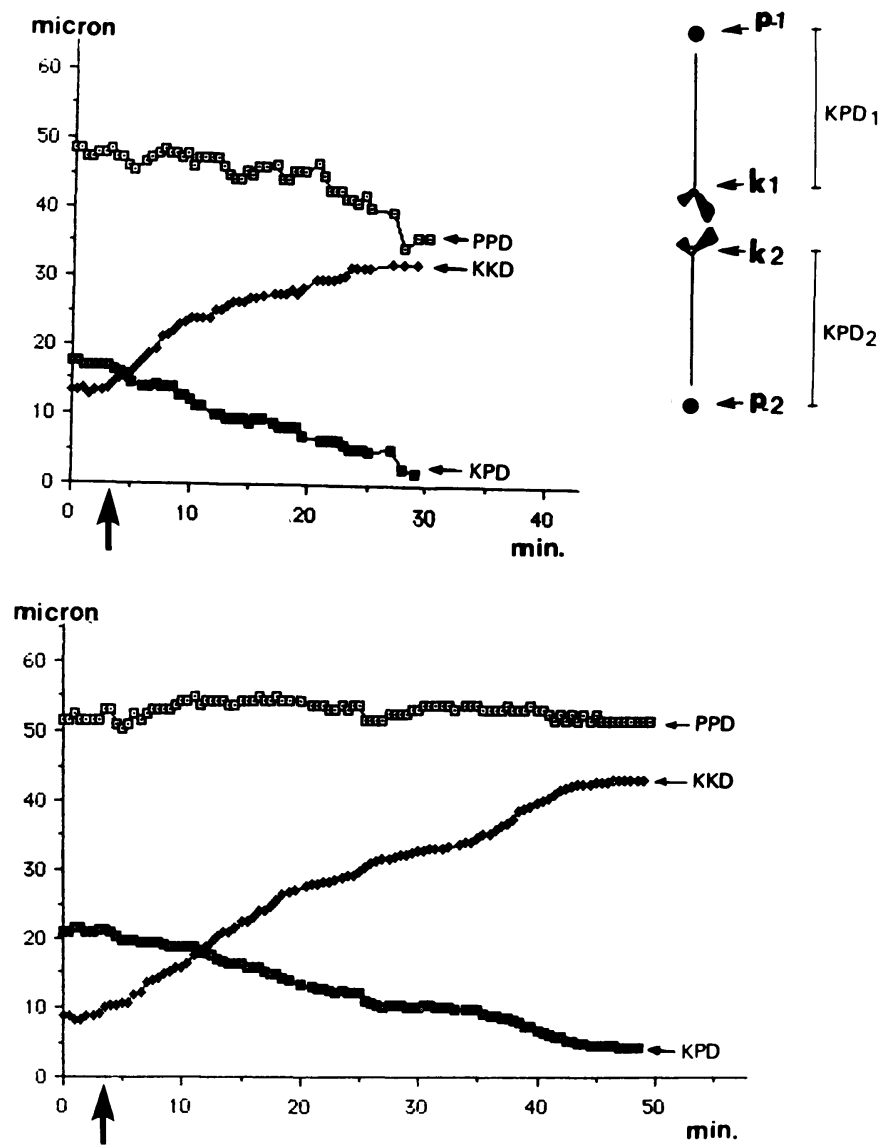

Fig. 3. Representative changes of the spindle parameters during anaphase of a control primary spermatocyte (upper figure) and a $\mathrm{D}_{2} \mathrm{O}$-treated primary spermatocyte (lower figure). PPD: Pole-to-pole distance (p1p2). KKD: Kinetochore-to-kinetochore distance or distance between kinetochores of homologous half-bivalents (k1k2). KPD: Kinetochore-to-pole distance $\left(\frac{\text { KPD1 + KPD2 }}{2}\right)$. The start of chromosome separation is indicated by larger arrows. Temperature was $26^{\circ} \mathrm{C}$.

TABLE 1. DuRATION OF ANAPHASE, RATE OF CHROMOSOME MOVEMENT, RATE OF KINETOCHORE-TO-POLE DISTANCE SHORTENING (mean $\pm \mathrm{SD}$ ).

\begin{tabular}{llcc}
\hline & Control & $40 \% \mathrm{D}_{2} \mathrm{O}-$ Carlson's solution \\
\hline 1. Anaphase duration & $28.3 \pm 7.0 \mathrm{~min}(8)$ & $36.5 \pm 5.0 \mathrm{~min}(9)$ \\
2. Rate of chromosome movement & $1.3 \pm 0.3 \mu \mathrm{m} / \mathrm{min}(9)$ & $0.9 \pm 0.2 \mu \mathrm{m} / \mathrm{min}(11)$ \\
3. Rate of Kinetochore-to-pole & $0.6 \pm 0.1 \mu \mathrm{m} / \mathrm{min}(10)$ & $0.5 \pm 0.1 \mu \mathrm{m} / \mathrm{min}(11)$ \\
& & \\
distance shortening & &
\end{tabular}

Numbers in parentheses indicate the number of observed cells. The temperature during observation ranged between $25^{\circ}-27^{\circ} \mathrm{C}$. The rate of chromosome movement and the rate of shortening of the kinetochoreto-pole distance were measured in early or early to mid-anaphase when the rates were almost constant. 


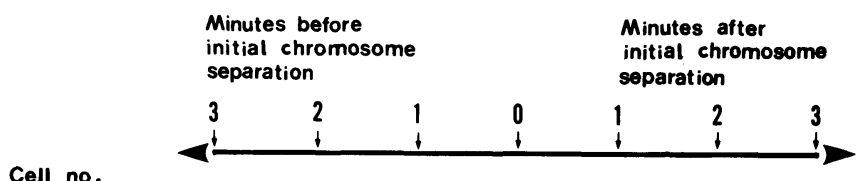

Cell no.

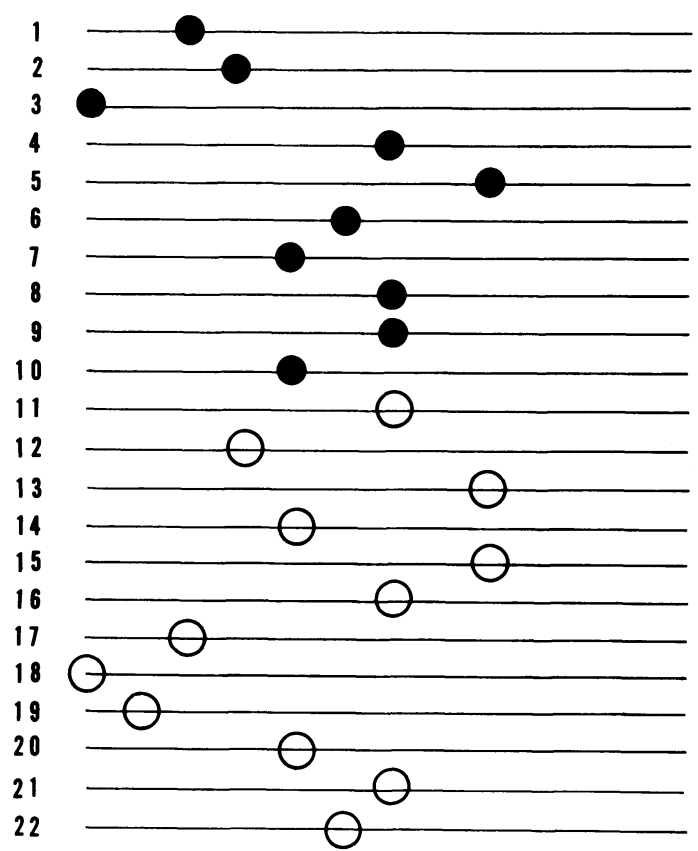

Fig. 4. Time relationship between the initiation of chromosome separation and beginning of kinetochore-to-pole distance shortening. The time at which bivalent kinetochore fibers of control (solid circles) and $\mathrm{D}_{2} \mathrm{O}$-treated (open circles) cells started to shorten are plotted. Temperatures ranged from $25^{\circ}$ to $27^{\circ} \mathrm{C}$.

chromosomal movement, KPD decreased at a rate not significantly different from the controls. On the average KPD during early to mid-anaphase, the period of fastest chromosomal movement, shortened to $0.6 \pm 0.1 \mu \mathrm{m}$ per minute in the control cells while in the $\mathrm{D}_{2} \mathrm{O}$-treated cells, it shortened to $0.5 \pm 0.1 \mu \mathrm{m}$ per minute (Table 1). In general, the control spindle elongated in early and mid-anaphase, but shortened at late anaphase (Fig. 3). The pole-to-pole distance (PPD) of the $\mathrm{D}_{2} \mathrm{O}$-treated spindles, in many occasions, did not fluctuate much.

\section{DISCUSSION}

In the present study, $40 \% \mathrm{D}_{2} \mathrm{O}$ was shown to cause a longer and more birefringent spindle in the primary spermatocytes of the grasshopper, Mongolotettix japonicus. The increase of the spindle BR was especially conspicuous in the kinetochore spindle fibers. This observation confirms the result of the previous work obtained in the spermatocyte of the same species (7). In addition, the enhancement of the spindle assembly by $\mathrm{D}_{2} \mathrm{O}$ is what could be expected from a number of investigations dealing with the $\mathrm{D}_{2} \mathrm{O}$ effects on the living mitotic spindle. 
As an explanation of the enhancement of spindle assembly by $\mathrm{D}_{2} \mathrm{O}$, increased hydrophobic interaction between tubulin molecules may be taken into consideration, since protein molecules in the cytoplasm might increase their hydrophobicity proportionally to the given concentration of $\mathrm{D}_{2} \mathrm{O}(9,13)$, and since the hydrophobic interaction of protein molecules is also involved in the assembly of microtubules. Thus, promotion of tubulin polymerization by $\mathrm{D}_{2} \mathrm{O}$ in vitro may be a direct reflection of the strengthened binding of tubulin molecules (4). In anaphase, kinetochore microtubules depolymerize and the distance between the pole and the chromosomes decreases (anaphase A). The microtubule disassembly might be responsible for driving the chromosomes poleward $(3,10)$. If $\mathrm{D}_{2} \mathrm{O}$ is involved in the modulation of hydrophobic interaction amongst tubulin molecules, $\mathrm{D}_{2} \mathrm{O}$ might decrease the speed of anaphase A. Investigation dealing with the effects of $\mathrm{D}_{2} \mathrm{O}$ on mitosis in eukaryotes revealed that application at more than $60 \%$ caused a structural stabilization of the mitotic apparatus $(11,12)$ and suppressed the mitotic events. On the other hand, application of $\mathrm{D}_{2} \mathrm{O}$ at concentrations below $45 \%$ did not inhibit anaphasic movement in sea urchin eggs $(13,14)$. The present experiment on grasshopper spermatocytes using $40 \% \mathrm{D}_{2} \mathrm{O}$ have revealed that although the anaphase was prolonged due to the longer spindle axis and slower chromosome movement, the KPD shortened at a rate not significantly different from that of the control. $\mathrm{D}_{2} \mathrm{O}$, therefore, did not affect the progression of anaphase A. In accordance with this result, thermodynamic analysis of the effect of $\mathrm{D}_{2} \mathrm{O}$ on the mitotic spindle in echinoderm eggs $(15,17)$ did not support the postulation that $\mathrm{D}_{2} \mathrm{O}$ strengthens the hydrophobic interaction between tubulin molecules. Furthermore, observation on the $\mathrm{Ca}^{2+}$-dependent deterioration of $\mathrm{BR}$ of isolated spindles in sea urchin eggs (18) showed that the rate of deterioration of the spindles pre-treated with $45 \% \mathrm{D}_{2} \mathrm{O}$ was essentially the same as in the control spindle. All these facts seem to be more consistent with the conclusion that $\mathrm{D}_{2} \mathrm{O}$ enhances spindle assembly by increasing the number of polymerizable tubulin molecules required for the assembly of the spindle $(15,16,17)$, the microtubule of which is assumed to be in a state of dynamic equilibrium with the monomeres in the tubulin pool (3).

Although $40 \% \mathrm{D}_{2} \mathrm{O}$ did not modify the process of anaphase $\mathrm{A}$, the chromosome movement was retarded in the $\mathrm{D}_{2} \mathrm{O}$-treated spindle. Our results have shown that the PPD did not fluctuate much during anaphase in the $\mathrm{D}_{2} \mathrm{O}$-treated cells. Because spindle poles were already wide apart in metaphase in the presence of $\mathrm{D}_{2} \mathrm{O}$, the separation of the poles (anaphase B) contributed little to the anaphasic chromosome movement. This may explain the slower chromosome movement in anaphase of the $\mathrm{D}_{2} \mathrm{O}-$ treated cells.

Acknowledgment. We wish to express our gratitude to Dr. Keiji Fujiwara of the National Cardiovascular Center Research Institute, Osaka, Japan, for his careful reading and valuable comments and Dr. T. Yoshida of Department of Pathology, Mie University, School of Medicine for his kind help for the quantitative analyses. We also wish to extend our thanks to the staffs of the Department of Pathology, Mie University, School of Medicine and the Sugashima Marine Biological Laboratory of Nagoya University, for their kind assistance during this work.

This work was partly supported by Grant-in-Aids for Scientific Research from the Ministry of Education, Science and Culture of Japan, numbered as: 60480020, 61304008, 6230004 and 62304062. 


\section{REFFERENCES}

1. Carlson, J.G. and M.E. Gaulden. Grasshopper neuroblast techniques. in Methods in Cell Physiology Vol. 1, ed. D.M. Prescott., Acad. Press, N.Y., pp. 229-275, 1964

2. Gross, P.R and W. SPINDEL. Heavy water inhibition of cell division: An approach to mechanism. N.Y. Acad. Sci. 90, 501-522, 1960

3. Inoue, S. and H. SAto. Cell motility by labile association of molecules. The nature of mitotic spindle fibers and their role in chromosome movement. J. Gen. Physiol. 50, 259-292, 1967

4. Iтон, T.J. and H. Sato. The effects of deutrium oxide $\left({ }^{2} \mathrm{H}_{2} \mathrm{O}\right)$ on the polymerization of tubulin in vitro. Biochem. Biophy. Acta. 800, 21-27, 1984

5. IzUTsu, K. Cine-micrographic studies on the mechanism of cell division. Meiosis in orthopteran spermatocytes II from metaphase to telophase. Mie Med. J. VII, 45-53, 1958

6. Izutsu, K. and S. TAKedA. Cine-micrographic analysis of spindle formation in normal and puromycin-treated spermatocytes of Chrysochraon japonicus. Mie Med. J. 1, 51-65, 1966

7. IzUTSU, K., H. Sato and Y. OHNuKI. Behaviour of mitotic spindles in dividing cells. Description of a film. in Cell Motility. Molecules and Organization, ed. S. Hatano, H. Ishikawa, H, Sato, Univ. of Tokyo Press, pp. 281-287, 1979

8. Izutsu, K., H. Sato, H. Nakabayashi and N. Aoki. The behaviour of spindle fibers and movement of chromosomes in dividing grasshopper spermatocytes. Cell Struct. Funct. 2, 119-113, 1977

9. KresheCK, G.C., H. Schneider and H.A. Scheraga. The effect of $\mathrm{D}_{2} \mathrm{O}$ on the thermal stability of proteins. Thermodynamic parameters for the transfer of model compounds from $\mathrm{H}_{2} \mathrm{O}_{2}$ to $\mathrm{D}_{2} \mathrm{O}$. J. Phys. Chem. 69, 3132-3144, 1965

10. Koshland, D.E., T.J. Mitchison and W. Kirschner. Polewards chromosome movement driven by microtubule depolymerization in vitro. Nature 331 (6156), 499-504, 1988

11. Marsland, D. and Y. Hiramoto. Cell division: Pressure-induced reversal of the antimeiotic effects of heavy water in the oocytes of the starfish, Asterias forbesi. J. Cell Physiol. 67, 13-21, 1966

12. Marsland, D. and A.M. Zimmerman. Structural stabilization of mitotic apparatus by heavy water in the cleaving Arbacia punctulata. Exp. Cell Res. 38, 306-313, 1965

13. SAto, H. The mitotic spindle. in Aging Gamet. Int. Symp. Seatle, pp. 19-49, 1973

14. SAto, H., G.W. Ellis and S. INOUE. Microtubular origin of mitotic spindle form birefringence. Demonstration of the applicability of Wiener's equation. J. Cell Biol. 67, 501-517, 1975

15. SATO, H. and J. BRYAN. The thermodynamics of molecular association in the mitotic spindle with or without heavy water $\left(\mathrm{D}_{2} \mathrm{O}\right)$. Zoological Sci. 5, 623-638, 1988

16. Sato, H., T. Kato, T.C. TAKahashi and T.J. IтоH. Analysis of $\mathrm{D}_{2} \mathrm{O}$ effects on in vivo and in vitro tubulin polymerization and depolymerization. in Biological Functions of Microtubules and Related structure. ed. H. Sakai, H. Mohri and G.G. Borisy, Acad. Press, Tokyo Inc., pp. 211-225, 1982

17. TAKahashi, T.C. and H. SAto. Thermodynamic analysis of the effect of $\mathrm{D}_{2} \mathrm{O}$ on mitotic spindles in developing sea urchin eggs. Cell Struct. 7, 349-357, 1987

18. TAKahASHI, T.C. and H. SATo. Effects of heavy water $\left(D_{2} O\right)$ on the length of mitotic period in developing sea urchin eggs. Cell Struct. Funct. 8, 367-365, 1984

(Received for publication, February 27, 1989) 